\title{
The Superior Therapeutic Properties of SOM230 Originate from Unique Structural Elements
}

\author{
Ian Lewis ${ }^{a \star}$, Rainer Albert ${ }^{\mathrm{a}}$, Wilfried Bauer ${ }^{\mathrm{a}}$, Nagarajan Chandramoulia, Janos Pless ${ }^{\mathrm{a}}$, Lukas Oberera, \\ Günter Bovermann ${ }^{\mathrm{a}}$, Joost van der Hoek ${ }^{\mathrm{b}}$, Viktor Boerlin ${ }^{\mathrm{a}}$, Steven W.J. Lamberts ${ }^{\mathrm{b}}$, Herbert A. \\ Schmid ${ }^{a}$, Gisbert Weckbeckera ${ }^{a}$, and Christian Bruns ${ }^{a}$
}

\begin{abstract}
A rational drug design approach involving transposition of functional groups from SRIF into a reduced size cyclohexapeptide template has led to the discovery of SOM230, a novel, stable cyclohexapeptide somatostatin mimic which exhibits unique high affinity binding to human somatostatin receptors (sst1-5). SOM230 has potent, long lasting inhibitory effects on growth hormone and insulin-like growth factor-1 release and is a promising development candidate currently under evaluation in phase II clinical trials.
\end{abstract}

Keywords: Cyclohexapeptide template $\cdot$ Solid phase synthesis $\cdot$ SRIF analogue $\cdot$ Superior therapeutic properties

\section{Introduction}

The unique pharmacological effects mediated by SRIF-14 [1] (1) involving broad inhibitory effects on the endocrine secretion of growth hormone $(\mathrm{GH})$, insulin, glucagon, gastrin, cholecystokinin (CCK) and vasoactive intestinal peptide (VIP) are derived from its universal high affinity binding to all somatostatin receptor subtypes sst1-5. In contrast, the octapeptide SMS 201-995 (2) which was introduced into clinical practice in 1987 for treatment of hormone-secreting pituitary adenomas [2-4], MK-678 (3) and closely related cyclohexapeptide analogues 4 and 5 [5-10], display high affinity for sst2 only, moderate or low affinity for sst3 and sst5 and no or low affinity for sst 1 and sst 4 (Table). Recently, a rational approach has successfully led to the discovery of a novel, stable cyclohexapeptide somatostatin analogue which exhibits unique binding to four of the five human somatostatin receptors [11-13]

\footnotetext{
${ }^{*}$ Correspondence: Dr. I. Lewis ${ }^{a}$

Tel.: +41613243762

Fax: +41613247821

E-Mail: ian.lewis@pharma.novartis.com

S-507.3.03

aNovartis Institutes of Biomedical Research

Transplantation and Oncology Departments

$\mathrm{CH}-4002$ Basel

bepartment of Internal Medicine

Section Endocrinology

Erasmus MC

Dr. Molewaterplein 40

NL-3015 GD Rotterdam, The Netherlands
}

sst 1 , sst2, sst3, and sst5, and consequently superior pharmacological properties compared to current therapies. This achievement was based on the original goal of this research project, aiming at the discovery of a small, stable SRIF-14 mimic exhibiting universal high affinity binding to sst1-5 and involving the transposing functional groups from SRIF-14 (1) into the reduced size, stable cyclohexapeptide analogues 6-15 illustrated in the Table and Fig. 1.

\section{Results and Discussion}

\subsection{Synthesis}

In this research, cyclohexapeptides were synthesised on solid phase using Fmoc/tBu strategy and the SASRIN ${ }^{\circledR}$ linker prior to cyclisation in solution (Scheme) [14]. Synthesis of the polymer bound linear peptide 16, affording the side chain protected linear peptide 17, illustrated in the Scheme, was achieved by a standard stepwise solid-phase procedure on a commercially available polystyrene resin containing the acid cleavable SASRIN ${ }^{\circledR}$ linker. The base-labile fluorenylmethoxycarbonyl (Fmoc) group was used for $\mathrm{N}_{\alpha}$-amino protection and side chains were protected by Boc protecting groups. The polymer bound linear peptide 16 was cleaved from its resin support by a short treatment with $2 \%$ TFA leaving its side chain protection intact. Subsequently the side chain protected linear peptide 17 was cyclised in DMF using diphenyl-phosphoryl-azide (DPPA). Finally side chain deprotection was achieved by treatment with 95\% TFA and after purification by RP-HPLC, SOM230 (15) was obtained in an overall yield of $20 \%$, and with 98\% purity by HPLC [15]. Its structural identity was confirmed by MS, NMR, and by amino acid analysis. Synthesis of the required hydroxyproline derivatives was carried out in solution as previously described [15].

\subsection{Medicinal Chemistry}

As a starting point for medicinal chemistry, pivotal structure-activity relationships gleaned from 'alanine-scanning' [15][16] (Fig. 2A), provided an important platform in our search for unique modifications transforming cyclohexapeptides exhibiting initial high selectivity [17-19] into SRIF mimics exhibiting high affinity binding to multiple ssts (Fig. 2B). An initial breakthrough emerged with the incorporation of $\operatorname{Tyr}(\mathrm{Bzl})^{5}$ into the cyclohexapeptide 6 (Fig. 1 and Fig. 2C), replacing Thr ${ }^{5}$, which in combination with $\mathrm{Phe}^{2}$ was designed to mimic $\mathrm{Phe}^{6}, \mathrm{Phe}^{7}, \mathrm{Thr}^{10}$, and Phe ${ }^{11}$ of SRIF-14 (1) (SRIF numbering). This substitution transformed the previously highly selective sst 2 analogue 5 into the cyclohexapeptide $\mathbf{6}$ exhibiting high affinity to sst 3 and sst5 in addition to sst2. Considering the influence of the rigid HyPro ${ }^{1}$ ring, substitution with the more flexible NMeSer ${ }^{1}$ provided a cyclohexapeptide 7 [20] (Fig. 1 and Fig. 2C) exhibiting increased affinity to sst1, sst3, and sst5 albeit accompanied with reduced affinity to sst2. Investigation of the incorporation of a flex- 
Table. Binding of somatostatin analogues to SRIF receptor subtypes (pKi)

\begin{tabular}{|c|c|c|c|c|c|c|}
\hline & Structure & sst1 & sst2 & sst3 & sst4 & sst5 \\
\hline (1) SRIF-14 & H-Ala-Gly-Cys-Lys-Asn-Phe-Phe-Trp-Lys-Thr-Phe-Thr-Ser-Cys-OH & 9.4 & 10.1 & 9.6 & 9.1 & 9.3 \\
\hline (2) SMS 201-995 & H-DPhe-Cys-Phe-DTrp-Lys-Thr-Cys-Thr(ol) & 6.7 & 9.3 & 7.9 & 6.0 & 8.2 \\
\hline (3) MK-678 & cyclo[MeAla-Tyr-DTrp-Lys-Val-Phe] & $<6.0$ & 10.1 & 7.5 & $<6.0$ & 7.9 \\
\hline (4) L363,301 & cyclo[Pro-Phe-DTrp-Lys-Thr-Phe] & 6.2 & 9.2 & 6.9 & $<7.0$ & 7.4 \\
\hline (5) & cyclo[HyPro-Phe-DTrp-Lys-Thr-Phe] & $<6.0$ & 9.7 & 6.7 & $<6.0$ & $<6.0$ \\
\hline (6) & cyclo[HyPro-Phe-DTrp-Lys-Tyr(Bzl)-Phe] & 7.2 & 9.1 & 8.8 & 6.5 & 9.5 \\
\hline (7) & cyclo[MeSer-Tyr-DTrp-Lys-Tyr(Bzl)-Phe] & 7.6 & 8.8 & 9.1 & $<7.0$ & 9.7 \\
\hline (8) & cyclo[MeLys-Phe-DTrp-Lys-Tyr(Bzl)-Phe] & 7.7 & 7.6 & 8.5 & $<7.0$ & 9.2 \\
\hline (9) & cyclo[(diaminoethylcarb.)MeSer-Tyr-DTrp-Lys-Tyr(Bzl)-Phe] & 7.8 & 9.1 & 8.5 & $<7.0$ & 9.7 \\
\hline (10) & cyclo[(diaminoethylcarb.)HyPro-Phe-DTrp-Lys-Tyr(Bzl)-Phe] & 8.4 & 8.7 & 9.1 & 6.3 & 9.4 \\
\hline (11) & cyclo[(diaminoethylcarb.)HyPro-His-DTrp-Lys-Tyr(Bzl)-Phe] & 8.4 & 9.1 & 9.1 & $<7.0$ & 8.5 \\
\hline (12) & cyclo[(acetyl-diaminoethylcarb.)HyPro-Phe-DTrp-Lys-Tyr(Bzl)-Phe] & 7.6 & 8.3 & 9.1 & 6.2 & 9.8 \\
\hline (13) & cyclo[(DTPA-diaminoethylcarb.)HyPro-Phe-DTrp-Lys-Tyr(Bzl)-Phe] & 8.0 & 9.0 & 9.2 & 6.5 & 9.6 \\
\hline (14) & cyclo[(diaminoethylcarb.)HyPro-D-Phg-DTrp-Lys-Tyr(Bzl)-Phe] & 6.0 & 6.1 & 7.7 & 6.1 & 9.3 \\
\hline (15) SOM230 & cyclo[(diaminoethylcarb.)HyPro-Phg-DTrp-Lys-Tyr(Bzl)-Phe] & 8.2 & 9.0 & 9.1 & $<7.0$ & 9.9 \\
\hline
\end{tabular}

ible basic extension by replacement of the NMeSer ${ }^{1}$ with NMeLys ${ }^{1} \mathbf{8}$ (Fig. 1 and Fig. 2C) provided a very slight increase in sst1 affinity, however this was accompanied by a large reduction in sst 2 affinity combined with reduced sst 3 and sst5 affinities. Re- placement of NMeLys ${ }^{1}$ with the basic diaminoethyl extension attached to NMeSer ${ }^{1}$ via a urethane linkage provided cyclohexapeptide 9, for the first time exhibiting intermediate affinity binding to sst1 along with high affinity binding to sst 2 and sst 5 , com-
Fig. 1. Structures of SRIF-14, SMS 201-995, SOM230 and related analogues

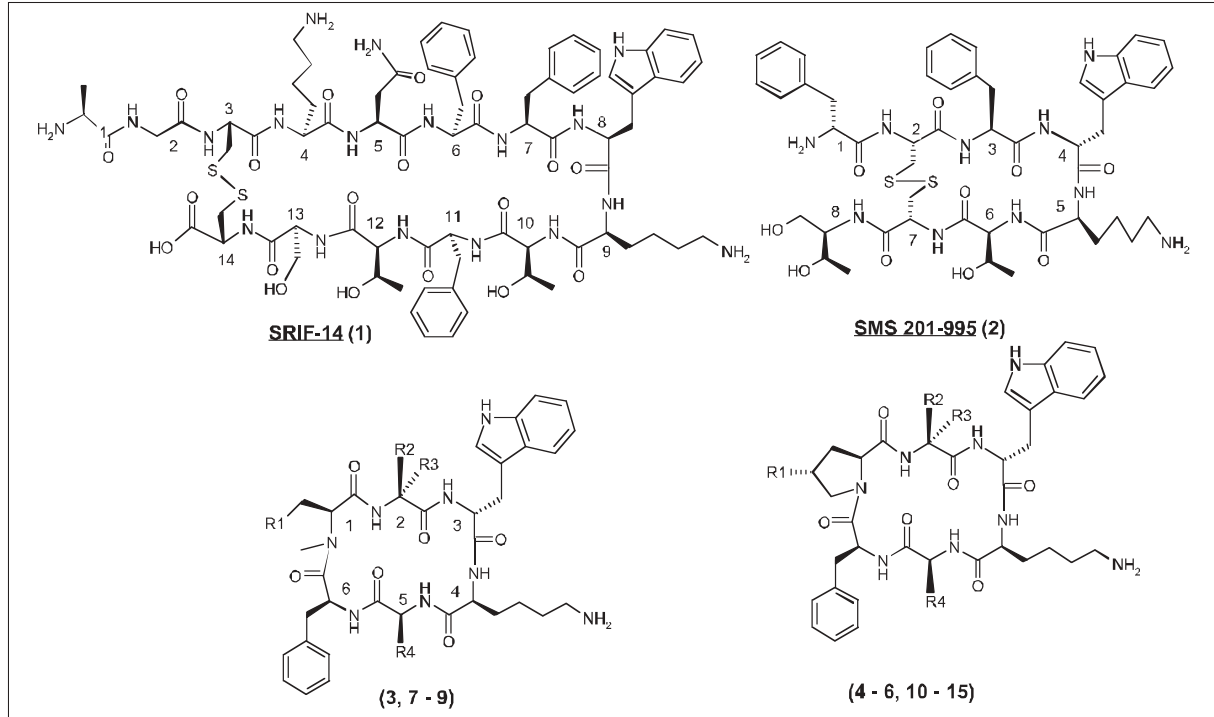

3: $\mathrm{R} 1=\mathrm{H}, \mathrm{R} 2=\mathrm{CH}_{2} \mathrm{C}_{6} \mathrm{H}_{5} \mathrm{OH}(\mathrm{Tyr}), \mathrm{R} 3=\mathrm{CH}\left(\mathrm{CH}_{3}\right)_{2}, \mathrm{MK}-678$

7: R1 = C $\mathrm{CH}_{2} \mathrm{OH}, \mathrm{R2}=\mathrm{CH}_{2} \mathrm{C}_{6} \mathrm{H}_{5} \mathrm{OH}, \mathrm{R} 3=\mathrm{CH}_{2} \mathrm{CH}_{5} \mathrm{OCH}_{2} \mathrm{C}_{6} \mathrm{H}_{6}$ (TyrosineBenzyl)

8: $\mathbf{R} 1=\left(\mathrm{CH}_{2}\right)_{3} \mathrm{NH}_{2}, \mathbf{R} 2=\mathrm{CH}_{2} \mathrm{C}_{6} \mathrm{H}_{6}, \mathbf{R} 3=\mathrm{CH}_{2} \mathrm{CH}_{5} \mathrm{OCH}_{2} \mathrm{C}_{6} \mathrm{H}_{6}$ (TyrosineBenzyl)

9: $\mathrm{R} 1=\mathrm{O}(\mathrm{CO}) \mathrm{NH}\left(\mathrm{CH}_{2}\right) \mathrm{NH}_{2}, \mathrm{R} 2=\mathrm{CH}_{2} \mathrm{C}_{6} \mathrm{H}_{6}(\mathrm{Phe}), \mathbf{R} 3=\mathrm{CH}_{2} \mathrm{C}_{6} \mathrm{H}_{5} \mathrm{OCH}_{2} \mathrm{C}_{8} \mathrm{H}_{6}$ (TyrosineBenzyl)

4: R1 = H, R2 = $\mathrm{CH}_{2} \mathrm{C}_{6} \mathrm{H}_{6}$ (Phe), R3 = H, R4 = CH(OH) $\mathrm{CH}_{3}$ (Threonine)

5: R1 $=\mathrm{OH}, \mathbf{R 2}=\mathrm{CH}_{2} \mathrm{C}_{3}\left(\mathrm{Phe}, \mathrm{R} 3=\mathrm{H}, \mathrm{R} 4=\mathrm{CH}(\mathrm{OH}) \mathrm{CH}_{3}(\mathrm{ThreOnine)}\right.$

6: $\mathrm{R} 1=\mathrm{OH}, \mathrm{R2}=\mathrm{CH}_{2} \mathrm{C}_{6} \mathrm{H}_{6}$ (Phe), $\mathrm{R3}=\mathrm{H}, \mathrm{R} 4=\mathrm{CH}_{2} \mathrm{C}_{6} \mathrm{H}_{5} \mathrm{OCH}_{2} \mathrm{C}_{6} \mathrm{H}_{6}$ (TyrosineBenzyl)

10: $\mathbf{R 1}=\mathrm{O}(\mathrm{CO}) \mathrm{NH}\left(\mathrm{CH}_{2}\right)_{2} \mathrm{NH}_{2}, \mathbf{R} 2=\mathrm{CH}_{2} \mathrm{C}_{6} \mathrm{H}_{6}(\mathrm{Phe}), \mathbf{R 3}=\mathrm{H}, \mathbf{R} 4=\mathrm{CH}_{2} \mathrm{C}_{6} \mathrm{H}_{5} \mathrm{OCH}_{2} \mathrm{C}_{6} \mathrm{H}_{6}(\mathrm{TyrosineBenzyl})$

11: R1 = O(CO) NH( $\left.\mathrm{CH}_{2}\right)_{2} \mathrm{NH}_{2}, \mathrm{R} 2=\mathrm{CH}_{2} \mathrm{C}_{4} \mathrm{H}_{4} \mathrm{~N}_{2}$ (Histidine), R3 = H, R4 = $\mathrm{CH}_{2} \mathrm{C}_{6} \mathrm{H}_{5} \mathrm{OCH}_{2} \mathrm{C}_{6} \mathrm{H}_{6}\left(T_{\text {TrosineBenzyl) }}\right.$

12: $R 1=O(C O) N H\left(C_{2}\right)_{2} N H A c, R 2=\mathrm{CH}_{2} \mathrm{C}_{6} \mathrm{H}_{6}($ Phe $), \mathrm{R} 3=\mathrm{H}, \mathrm{R} 4=\mathrm{CH}_{2} \mathrm{C}_{6} \mathrm{H}_{5} \mathrm{OCH}_{2} \mathrm{C}_{6} \mathrm{H}_{6}\left(\mathrm{~T}_{6}\right.$ rosineBenzyl)

13: R1 = O(CO)NH( $\left.\mathrm{CH}_{2}\right)_{2} \mathrm{NH}-\mathrm{DTPA}, \mathrm{R} 2=\mathrm{CH}_{2} \mathrm{C}_{6} \mathrm{H}_{6}$ (Phe), R3 = H, R4 = $\mathrm{CH}_{2} \mathrm{C}_{6} \mathrm{H}_{5} \mathrm{OCH}_{2} \mathrm{C}_{6} \mathrm{H}_{6}$ (TyrosineBenzyl)

14: $\mathbf{R} 1=\mathbf{O}(\mathrm{CO}) \mathrm{NH}\left(\mathrm{CH}_{2}\right)_{2} \mathrm{NH}_{2}, \mathbf{R 2}=\mathrm{H}, \mathbf{R} 3=\mathrm{C}_{6} \mathrm{H}_{6}(\mathrm{D}-\mathrm{Phg}), \mathbf{R} 4=\mathrm{CH}_{2} \mathrm{C}_{6} \mathrm{H}_{5} \mathrm{OCH}_{2} \mathrm{C}_{6} \mathrm{H}_{6}($ TyrosineBenzyl)

15: $\mathrm{R} 1=\mathrm{O}(\mathrm{CO}) \mathrm{NH}\left(\mathrm{CH}_{2}\right)_{2} \mathrm{NH}_{2}, \mathrm{R} 2=\mathrm{C}_{6} \mathrm{H}_{6}(\mathrm{Phg}), \mathrm{R} 3=\mathrm{H}, \mathrm{R} 4=\mathrm{CH}_{2} \mathrm{C}_{6} \mathrm{H}_{5} \mathrm{OCH}_{2} \mathrm{C}_{6} \mathrm{H}_{6}($ TyrosineBenzyl), som230 bined with continued high affinity binding to sst3. Further improvement in the sst1 affinity, along with improved sst3 affinity, could be obtained by attaching the basic diaminoethyl extension to the more rigid HyPro $^{1}$ via a urethane linkage providing cyclohexapeptide 10, where good affinities to sst 2 and sst 5 were maintained (Fig. 1 and Fig. 2C). Substitution of $\mathrm{Phe}^{2}$ with $\mathrm{His}^{2}$ provided analogue 11 which exhibited very high affinities to both sst 2 and sst 3 along with continued high affinities to sst 1 and sst5 (Fig. 1 and Fig. 2D). The importance of the basic extension was confirmed by capping the amino terminus with acetyl, providing analogue 12 (Fig. 1 and Fig. 2D) where high affinities to sst2, sst 3 , and sst5 were maintained in the presence of significantly reduced affinity to sst1. The attractive therapeutic and diagnostic opportunities of radiolabelled SRIF analogues, where the somatostatin mimic is conjugated with a chelating agent, led us to utilize the hydroxyproline urethane extension for the attachment of the chelator DTPA providing the novel DTPA-cyclohexapeptide 13 (Fig. 1, Fig. 2D, and Scheme). The DTPA chelator was attached to SOM230 (15) using the $\varepsilon$-t-butyloxycarbonyl-Lys ${ }^{4}$ protected cyclohexapeptide and reacting with DTPA dianhydride in an analogous manner to the synthesis of $\left[{ }^{111} \mathrm{In}\right.$-DTPA-D-Phe $\left.{ }^{1}\right]$-octreotide [21][22]. Interestingly, although DTPA is linked through an amide bond, 13 importantly maintained high affinity binding to sst1, sst2, sst3, and sst5 (Fig. 2D) opening new avenues for diagnostic and therapeutic applications of reduced size universal cyclohexapeptide radiolabelled SRIF mimics. 
The final optimisation of the cyclohexapeptide SRIF mimic was achieved by adjusting the aromatic groups with the replacement of $\mathrm{Phe}^{2}$ with phenylglycine ${ }^{2}$ $\left(\mathrm{Phg}^{2}\right)$ in combination with $\operatorname{Tyr}(\mathrm{Bzl})^{5}$ and the diaminoethylcarbamoyl-Pro ${ }^{1}$ basic extension, providing SOM230 (15) (Fig. 1, Scheme, and Fig. 2D) [15]. However, it was considered to be extremely interesting in terms of conformation, that analogue 14, where the D-Phg is incorporated in position 2 instead of L-Phg in SOM230 (15), exhibits a profoundly different sst binding profile with very high affinity to sst5, moderate affinity to sst 3 and low affinities to the remaining ssts (Fig. 1 and Fig. 2D). This illustrated the broad potential of cyclohexapeptide SRIF mimics incorporating unique structural elements for a full palette of selectivities in sst binding profiles.

\subsection{Solution Structure of SOM230 and Structural Comparison to SMS 201-995}

Since receptor binding sites and bound conformation structures of ligands for ssts are unknown, 3D-structure determination of the ligands in solution and in crystalline form has been utilised to improve understanding of structure-activity relationships. The 3D-structure determination of SOM230 in solution was made on the basis of NMR and molecular dynamics simulation, enabling for the first time comparison of the conformational features of the multiple sst binding cyclohexapeptide SOM230 (15) with the structure of the cysteine-cys-

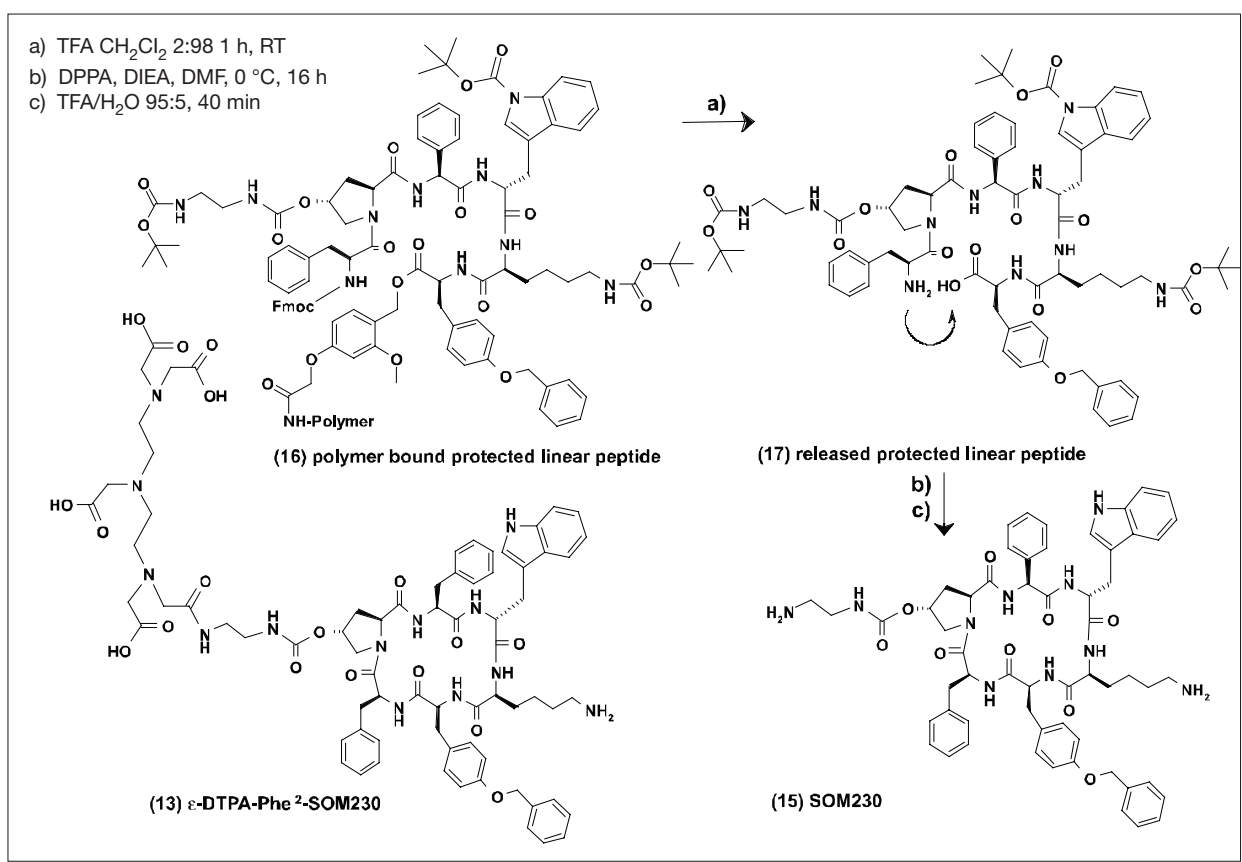

Scheme. Synthesis of SOM230: Solid phase assembly and solution phase cyclisation

teine bridged SMS 201-995 (2), which binds predominantly to sst2 and sst5 (Fig. 3) [23]. The four structural backbone NOEs detected in the NOESY spectrum of SOM230 in $\mathrm{H}_{2} \mathrm{O}$ were assigned to $\mathrm{Phg}^{2}-$ $\mathrm{NH} / \mathrm{Phe}^{6}-\alpha$ (medium), Phe $^{6}-\alpha /$ HyPro $^{1}-\alpha$

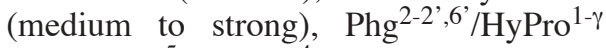
(weak), $\mathrm{Tyr}^{5}$-NH/Lys ${ }^{4}-\mathrm{NH}$ (strong), and the temperature coefficient of $\mathrm{Phg}^{2}-\mathrm{NH}$ indicated a hydrogen bond (Fig. 3A and Fig. 3B). The molecular dynamics simulations were performed with the program
CHARMm (Axelrys all-hydrogen force field) and the initial conformation was generated from an NMR-structure of the similar peptide $\mathbf{1 1}$ with a His instead of a Phg in position 2. The cyclohexapeptide was inserted into a cubic waterbox of 37.2 A length containing 1728 molecules with periodic boundary conditions. Four simulations were performed. The total simulation time was $46 \mathrm{~ns}$ ( 22 and $24 \mathrm{~ns}$ for each simulation) and $36 \mathrm{~ns}$ (29 ns and $7 \mathrm{~ns})$ at $300 \mathrm{~K}$ and $330 \mathrm{~K}$, respectively. In the four

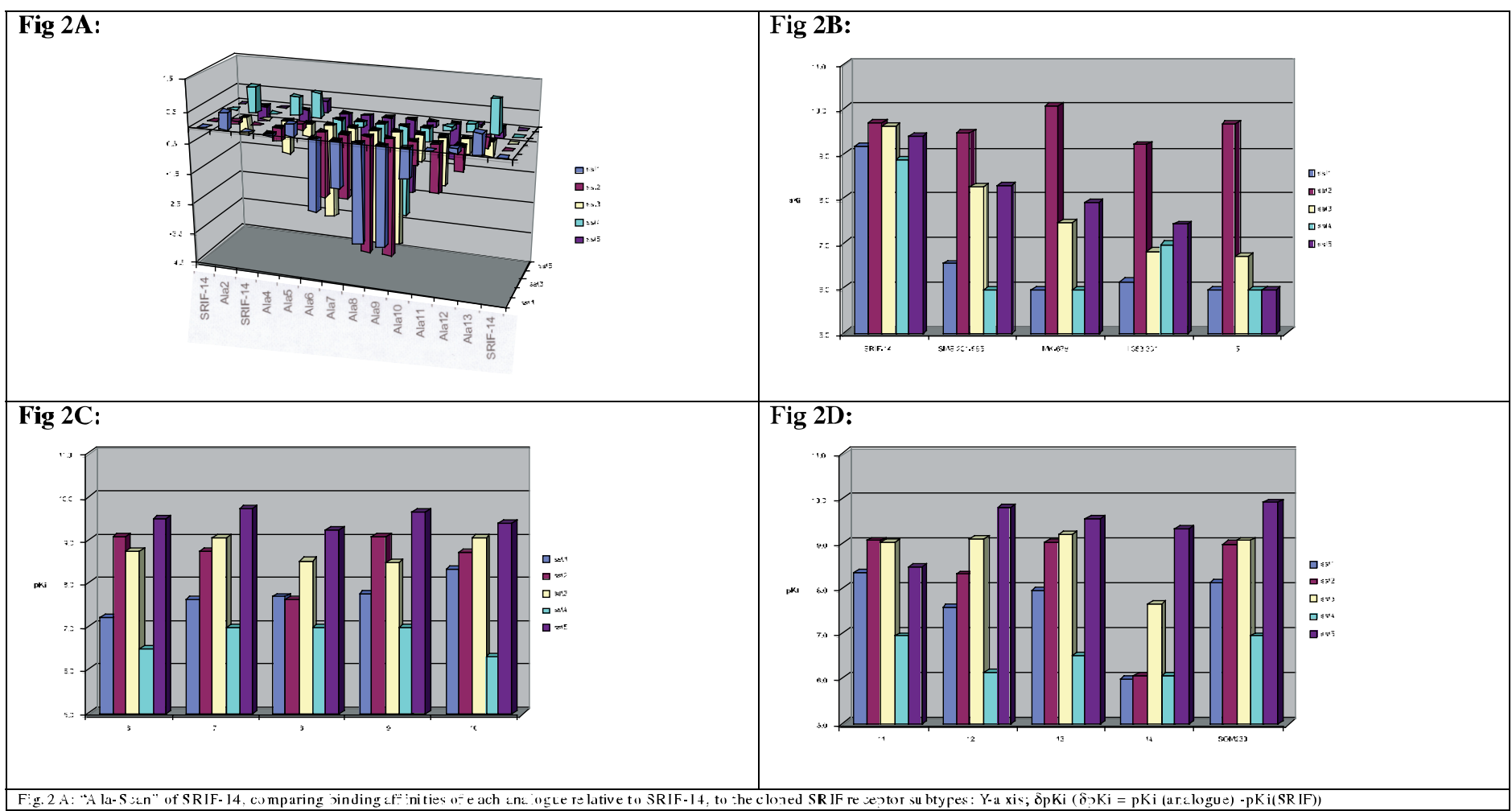

Fig. 2. 'Ala-Scan', drug design, structure-activity relationships 


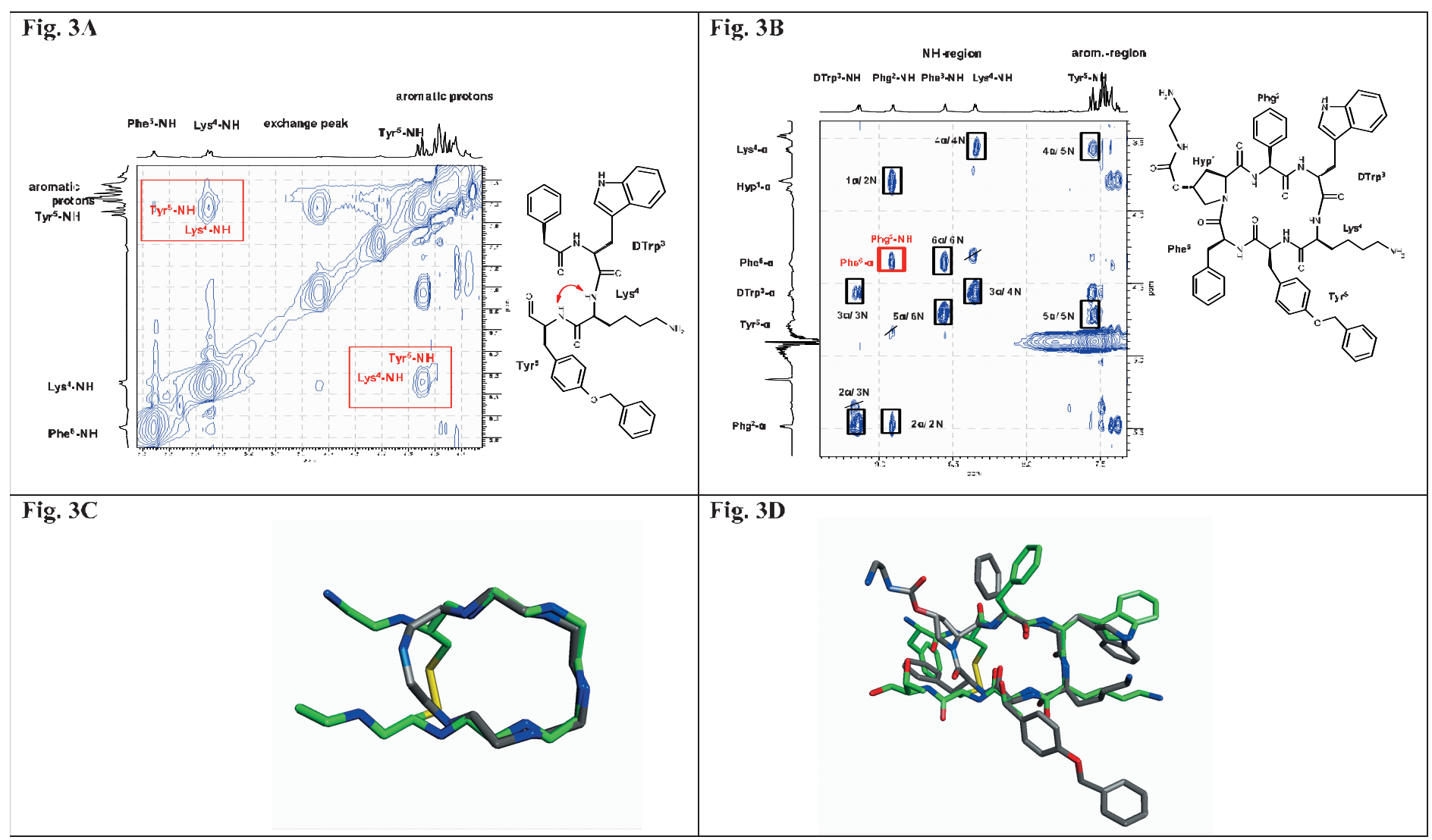

Fig. 3. Solution structure of SOM230 and structural comparison to SMS 201-995

simulations, all of the four experimentally measured NOE distances are satisfied. The $\mathrm{H}$ bond between $\mathrm{Phg}^{2}-\mathrm{NH}$ and $\mathrm{Tyr}^{5}$ $\mathrm{CO}$ is present most of the time during the simulation (a distance cutoff of $2.7 \AA$ has been used). During one of the simulations at $300 \mathrm{~K}$, three clusters were found, using a cutoff of $1 \AA$ on the $\mathrm{C}-\alpha$ atoms. The most populated cluster has a percentage of $73 \%$, the second one $16 \%$ and the least populated one $11 \%$.

The X-ray structure analysis of SMS 201-995 (2) reveals three structures in the crystalline state, where one of them corresponds to the structure observed in solution. This particular structure of SMS 201-995 (2) was superimposed with the calculated structure of SOM230 (15) (Fig. 3C). The backbones and the side chains of the $\beta$-turn forming D-Trp ${ }^{4}$ and Lys ${ }^{5}$ show an almost perfect match from $\mathrm{Phg}^{2}$ to $\mathrm{Tyr}^{5}$ in SOM230 (15) and $\mathrm{Phe}^{3}$ to $\mathrm{Thr}^{6}$ in SMS 201-995 (2), respectively. The diaminoethylcarb.-HyPro ${ }^{1}$ lysine mimic has been found to be extended outwards from the cyclohexapeptide backbone and is pivotal in providing high affinity binding to sst1 (Fig. 3D). The aromatic ring of $\mathrm{Phg}^{2}$, covering roughly the volume of the corresponding Phe in SMS 201-995 (2), was considered to be responsible for the conservation and stability of the active backbone conformation of SOM230 (15) and furthermore it is postulated to contribute to exceptionally high affinity to sst5, since in com- parison, the SOM230 analogue with $\mathrm{His}^{2}$ instead of $\mathrm{Phg}^{2}$ shows lower affinity to sst5. The 4'-O-benzyl-Tyr ${ }^{5}$ side chain exceeds the space of the $\mathrm{Thr}^{6}$ in SMS 201-995 (2) and has a distinctly different contribution to the binding of SOM230 (15), resulting in a high affinity to sst3 and sst5. Finally, the backbone part of the second turn in SOM230 (15), formed by $\mathrm{Phe}^{6}$ and $\mathrm{HyPro}^{1}$ is clearly displaced from the space of the disulfide bridge in SMS 201-995 (2) (Fig. 3D). This constellation of unique structural elements and their profound conformational influence enables the reduced size, stable cyclohexapeptide SOM230 (15) to mimic the much more flexible, universal tetradecapeptide SRIF-14 (1), until now unprecedented for a cyclohexapeptide scaffold. Indeed, the extent of the influence of these unique structural elements is highlighted by the fascinating contrasting sst binding profile of diastereomeric D-Phg ${ }^{2}$-SOM230 (14) exhibiting very high affinity to sst5, moderate affinity to sst 3 and low affinities to the remaining ssts (Fig. 2D).

\section{Pharmacology}

\subsection{Inhibition of Growth Hormone (GH) Release in vitro by SOM230}

The inhibitory effect of SOM230 (15) on growth hormone releasing hormone $(\mathrm{GHRH})$-induced $\mathrm{GH}$ release was measured in vitro using primary cultures of rat pituitary cells. Pituitary cells were cultured for $4 \mathrm{~d}$ as described previously [24] and incubated with (1-29) GHRH amide (0.3 $\mathrm{nM} / \mathrm{l})$ for $3 \mathrm{~h}$ in the presence of different doses of SOM230. SRIF-14 and SMS 201995 inhibited the $\mathrm{GH}$ release in vitro at nanomolar concentrations. In accordance with its high binding affinity for sst 2 and especially sst5, SOM230 (15) most effectively inhibited in a dose-dependent manner the GHRH-induced $\mathrm{GH}$ release in vitro with an $\mathrm{IC}_{50}$ of $0.4 \pm 0.1 \mathrm{nM}(\mathrm{n}=5)$ indicating its high potency for $\mathrm{GH}$ inhibition (Fig. 4A). The $\mathrm{IC}_{50}$ values for SRIF-14 (1) and SMS 201-995 (2) measured under the same experimental conditions were $1.5 \pm 0.3 \mathrm{nM}$ and $1.3 \pm 0.2 \mathrm{nM}$, respectively, indicating a 3-4 fold higher potency of SOM230 (15).

\subsection{Effect of SOM230 and SMS 201 995 on Growth Hormone (GH) Re- lease in Rats}

The effect of SOM230 (15) and SMS 201-995 (2) on GHRH stimulated GH release in rats was investigated in unrestrained freely moving male Lewis rats (200-250 g) using the Harward Swivel method. This method allowed the i.v. application of compounds as well as repeated and stress-free blood sampling in rats via two catheters which have been surgically implanted into $a$. and $v$. femoralis one day before the experiment. Blood sampling $(250 \mu \mathrm{l}$ each) started $1 \mathrm{~h}$ after $i . v$. application of SOM230 (15), SMS 201-995 (2) (10 $\mu \mathrm{g} / \mathrm{kg}$ ) or saline ( $\mathrm{n}=4$ each group). Imme- 


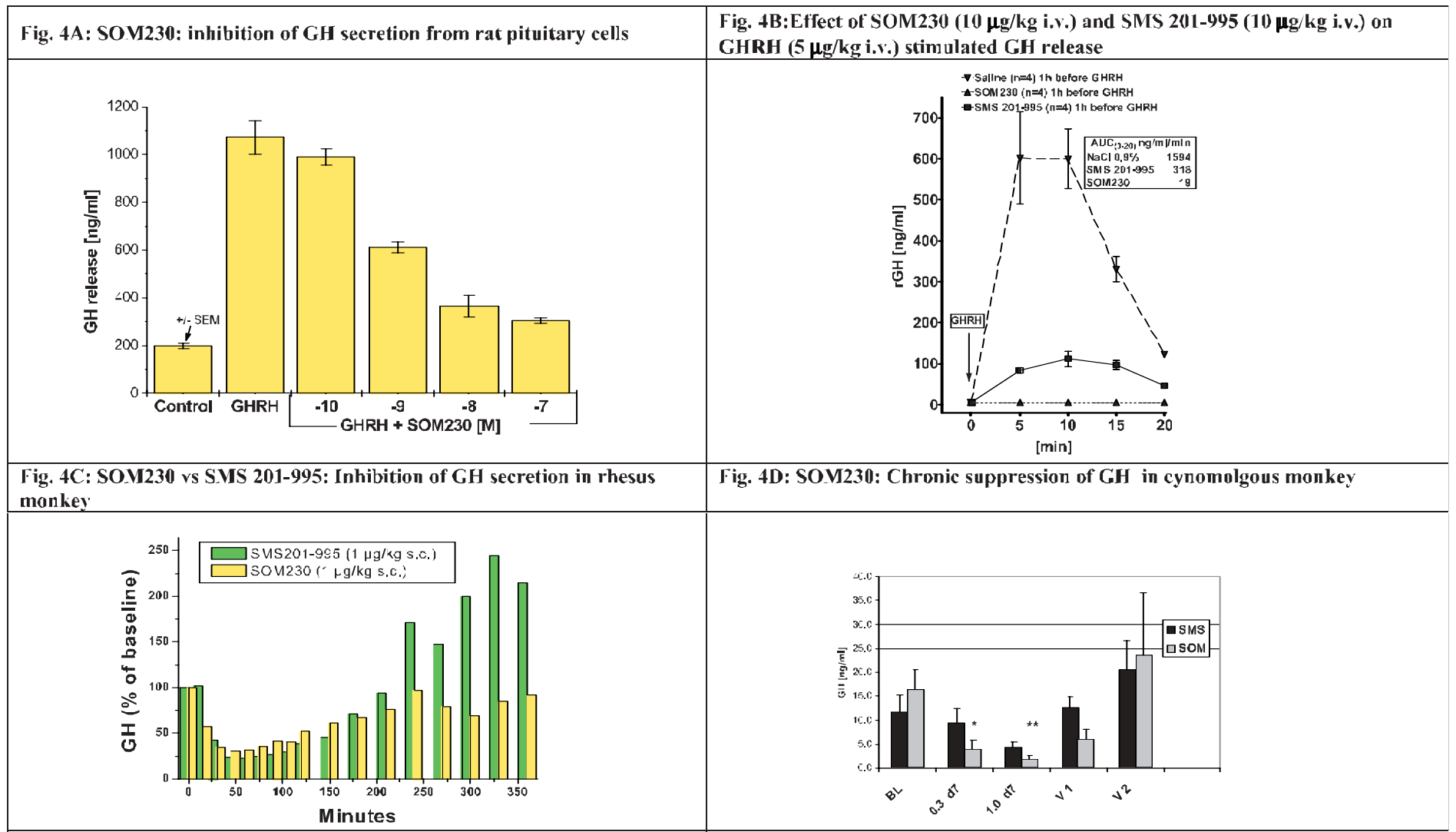

Fig. 4. Inhibition of GH secretion

diately after the first sampling GHRH was applied i.v. as a bolus at a concentration of $5 \mu \mathrm{g} / \mathrm{kg}$ and blood samples were collected in EDTA tubes 5, 10, 15, and 20 min later. Rat GH was determined using a commercial radio-immuno assay (Amersham Bioscience; rat GH RIA \#RPA551). As shown in Fig. 4B GHRH caused a rapid increase in $\mathrm{GH}$ release within $5 \mathrm{~min}$ after the injection, which rapidly declined within $20 \mathrm{~min}$. Compared to the saline treated control animals, SMS 201-995 (2) and SOM230 (15) caused a $80 \%$ and $99 \%$ inhibition of the $\mathrm{GH}$ release (measured as area under curve AUC), respectively, under these conditions. These data correspond well with the previously observed stronger inhibitory effect of SOM230 vs. SMS 201-995 on unstimulated GH levels in rats $6 \mathrm{~h}$ after drug application [24].

\subsection{Effect of SOM230 on Growth Hormone (GH) Release in Rhesus Monkey and Cynomolgus Monkey}

The endocrine profile of SOM230 (15) was studied both in rhesus and cynomolgus monkeys to assess its cross-species pharmacology in comparison to SMS 201-995 (2) [25]. SOM230 (15) and SMS 201-995 (2) were administered s.c. at a dose of 1.0 $\mu \mathrm{g} / \mathrm{kg}$ in male rhesus monkeys. Blood samples were collected during a $6 \mathrm{~h}$ follow up period and plasma was analysed for changes of basal hormone levels. Both analogues elicited similar inhibitory effects up to $3 \mathrm{~h}$ post injection (Fig. 4C). Thereafter the low dose of SMS 201-995 (2) was associated with a rebound, i.e. an increase of $\mathrm{GH}$ levels above initial basal values. By contrast, no rebound phenomenon was observed in SOM230-treated rhesus monkeys. On the other hand, SOM230 (15) and SMS 201-995 (2) inhibited GH in the same dose range with $\mathrm{ID}_{50}$ values of $0.50 \mu \mathrm{g} / \mathrm{kg}$ s.c and $0.40 \mu \mathrm{g} / \mathrm{kg}$ s.c. respectively.

To address long-term effects of SOM230 (15) on GH levels, cynomolgus monkeys were infused continuously for a 2 week treatment period with SOM230, or for comparison SMS 201-995. In the first week compounds were given at a rate of 0.3 $\mu \mathrm{g} / \mathrm{kg} / \mathrm{h}$ and in the following week at 1.0 $\mu \mathrm{g} / \mathrm{kg} / \mathrm{h}$ (Fig. 4D) [25]. The effect of SOM230 on GH levels was again very pronounced and superior to SMS 201-995 indicating that it exerts not only short-term (Fig. 4C) but also chronic inhibitory effects on GH secretion with a clear tendency for inhibition also during the washout phase (Fig. 4D). This observation in cynomolgus monkeys supports the notion of a long duration of action of SOM230 (15) already detected in acute studies in rat. Plasma insulin, glucagon and glucose levels remained unchanged on day 7 of the high dose infusion period (data not shown), while IGF-1 plasma levels dropped significantly from $1402 \pm 100 \mathrm{ng} / \mathrm{ml}$ to $896 \pm 47$ $\mathrm{ng} / \mathrm{ml}$ ( $\mathrm{p}=0.001, \mathrm{t}$-test). SMS 201-995 (2) did not induce a significant drop in IGF-1 levels under these conditions [25].

\section{Human Proof of Concept Study}

Recently, the SRIF analogue SOM230 (15), exhibiting a near universal binding profile which was demonstrated to effectively suppress GH levels in normal monkeys and rodents [25], was administered for the first time in acromegalic patients in order to assess its efficacy in comparison to octreotide [26][27] (SMS 201-995 (2)). In a single dose proof-of-concept study, $100 \mu \mathrm{g}$ octreotide (2), 100 and $250 \mu \mathrm{g}$ SOM230 (15) were given s.c. to 12 patients with active acromegaly. 100 and $250 \mu \mathrm{g}$ SOM230 (15) dose-dependently suppressed GH levels from 2-8 $\mathrm{h}$ after administration $(-38 \pm 7.7 \%$ vs. $-61 \pm 6.7 \%$, respectively; $P<0.01)$. A comparable suppression of $\mathrm{GH}$ levels by octreotide (2) and $250 \mu \mathrm{g}$ SOM230 (15) was observed in eight patients $(-65 \pm 7 \%$ vs. $-72 \pm 7 \%$, resp.). In three patients, the acute $\mathrm{GH}$-lowering effect of $250 \mu \mathrm{g}$ SOM230 was significantly superior to that of octreotide $(-70 \pm 2 \% v s .-17$ $\pm 15 \%$, resp.; $P<0.01$ ). In one patient, the $\mathrm{GH}$-lowering effect of octreotide was better than that of SOM230. Furthermore, in vitro analysis of adenoma tissue from two operated patients showed relatively high $\mathrm{sst}_{5}$ and low sst ${ }_{2}$ mRNA expression levels in one patient only responsive to SOM230 treatment, suggesting a pivotal role for $\mathrm{sst}_{5}$ in mediating the suppressive effects of SOM230 in this patient [28][29]. Support for this role of $\mathrm{sst}_{5}$ comes from three pri- 
mary human prolactinoma cultures, in which the potent inhibition of prolactin release by SOM230 (octreotide was only weakly effective in one culture) was related to $\mathrm{sst}_{5}$, but not to $\mathrm{sst}_{2}$ mRNA. Furthermore, in two corticotroph adenomas SOM230 (15) but not octreotide (2) inhibited ACTH release, most likely mediated via sst $_{5}$ as this receptor subtype appeared to be predominantly expressed in five other immunohistochemically proven corticotroph adenomas. Since SOM230 has a broad profile of inhibition of in vivo and in vitro tumoral pituitary hormone release [30], probably mediated via $\mathrm{sst}_{2}$ and $\mathrm{sst}_{5}$, it is suggested that SOM230 has the potential to increase the number of acromegalic patients which can be biochemically controlled.

\section{Conclusions}

SOM230 (15) is a novel cyclohexapeptide incorporating unique structural elements and exhibiting an almost universal high affinity binding profile for four of the five SRIF receptor subtypes. Consequently, SOM230 (15) exerts potent and long-lasting inhibitory effects on the GH/IGF-1 axis in rats, monkeys, dogs and in humans demonstrates superior biochemical control in GH hypersecreting acromegalic patients compared to current therapies. In conclusion, SOM230 (15) may enable the full promise of somatostatin analogue therapy to be fulfilled [31-34].

Received: January 19, 2004

\section{SRIF Discovery}

[1] P. Brazeau, W. Vale, R. Burgus, N. Ling, M. Butcher, J. Rivier, R. Guillemin, Science 1973, 179, 77-79.

\section{Octapeptides}

[2] W. Bauer, U. Briner, W. Doepfner, R. Haller, R. Huguenin, P. Marbach, T. Petcher, J. Pless, Life Sci. 1980, 31, 1134-1140.

[3] R.Z. Cai, B. Szoke, R. Lu, D. Fu, T.W Redding, A.V. Schally, Proc. Natl. Acad. Sci. U.S.A. 1986, 83(6), 1896-900.

[4] S.W.J. Lamberts, A.J. Van Der Lely, W.W. De Herder, L.J. Hofland, New England Journal of Medicine 1996, 334, 246-254.

\section{Cyclohexapeptides}

[5] D.F. Veber, R.M. Freidinger, D.S. Perlow Jr, W.J. Palaveda, F.W. Holly, R.G. Strachan, R.F. Nutt, B.J. Arison, C. Homnick, W.C. Randall, M.S. Glitzer, R. Saperstein, R. Hirschmann, Nature 1981, 292, 55-58.

[6] D.F. Veber, 'Design of a highly active cyclic hexapeptide analogue of somatostatin', in 'Peptides Synthesis, Structure and Function', Proceedings of the Seventh American Peptide Symposium, Eds. D.H. Rich, V.J. Gross, 1983, pp. 685-694.

[7 D.F. Veber, R. Saperstein, R.F. Nutt, R.M. Freidinger, S.F. Brady, P. Curley, D.S. Per- low, W.J. Paleveda, C.D. Colton, A.G. Zacchei, Life Sci. 1984, 34(14), 1371-8.

[8] R.M. Freidinger, D.S. Perlow, W.C. Randall, R. Saperstein, B.H. Arison, D.F. Veber, Int. J. Pept. Protein Res. 1984, 23(2), 142-150.

[9] R F. Nutt, C.D. Colton, R. Saperstein, D.F. Veber, 'Side Chain Conformations of Somatostatin Analogs When Bound to Receptors', in 'Somatostatin', Ed. S. Reichlin, Plenum Publishing Corp. 1987, pp. 83-87.

[10] D.F. Veber, 'Design and discovery in the development of peptide analogs', in 'Peptides: Chemistry and Biology', Proceedings of the Twelfth American Peptide Symposium, Eds. J.A. Smith, J.E. Rivier, 1992, pp. 3-14.

\section{Receptor Subtypes}

[11] D. Hoyer, H. Luebbert, C. Bruns, NaunynSchmiedeberg's Archives of Pharmacology 1994, 350(5), 441-53.

[12] C. Bruns, G. Weckbecker, F. Raulf, K. Kaupmann, P. Schoeffter, D. Hoyer, H. Lubbert, 'Molecular and Cell Biological Aspects of Gastroenteropancreatic Neuroendocrine Tumor Disease', Annals of the New York Academy of Sciences 1994, 733, 138-46.

[13] C. Bruns, G. Weckbecker, F. Raulf, H. Lübbert, D. Hoyer, 'Characterization of somatostatin receptor subtypes. Somatostatin and its receptors', Wiley, Chichester (Ciba Foundation Symposium 190) 1995, pp. 89-110.

\section{Medicinal Chemistry, in vitro and in vivo Discovery of SOM230}

[14] I. Lewis, W. Bauer, R. Albert, N. Chandramouli, J. Pless, G. Engel, G. Weckbecker, C. Bruns, 'Rational approach to stable, universal somatostatin analogues with superior therapeutic potential', in 'Peptides: The Wave of the Future', Proceedings of the 17th American/2nd International Peptide Symposium, Eds. R. Houghten, M. Lebl, San Diego June 2001, pp. 718-720.

[15] I. Lewis, W. Bauer, R. Albert, N. Chandramouli, J. Pless, G. Weckbecker, C. Bruns, J. Med. Chem. 2003, 46, 2334-2344.

[16] J. Rivier, M. Brown, C. Rivier, N. Ling, W. Vale, 'Hypothalamic hypophysiotropic hormones', review on the design of synthetic analogs, in 'Peptides 1976', Ed. A. Loffet, Editions de l'Universités: Bruxelles, Belgium, 1976, V. pp. 427-521.

[17] R.H. Mattern, S.B. Moore, T.-A. Tran, J.K. Rueter, M. Goodman, Tetrahedron 2000, 56, 9819-9831.

[18] E. Falb, Y. Salitra, T. Yechezkel, M. Bracha, P. Litman, R. Olender, R. Rosenfeld, H. Senderowitz, S. Jiang, M. Goodman, Bioorg. Med. Chem. 2001, 9(12), 3255-3264.

[19] C. Bruns, F. Raulf, D. Hoyer, J. Schloos, H. Luebbert, G. Weckbecker, Metab. Clin. Exp. 1996, 44(8, Suppl. 1), 17-20.

[20] I. Lewis, W. Bauer, R. Albert, N. Chandra- mouli, J. Pless, G. Weckbecker, C. Bruns, 'The Superior Therapeutic Potential of SOM230 Originates from Unique Structural Elements', in 'Peptide Revolution: Genomics, Proteomics \& Therapeutics', Eds. M. Chorev, T.K.Sawyer, Proceedings of the 18th American Peptide Symposium, Boston, July 2003.

[21] W.H. Bakker, R. Albert, C. Bruns, W.A. Breeman, L.J. Hofland, P. Marbach, J. Pless, D. Pralet, B. Stolz, J.W. Koper, S.W.J. Lamberts, T.J. Visser, E.P. Krenning, Life Sci. 1991, 49, 1583-1591.

[22] P.M. Smith-Jones, B. Stolz, R. Albert, G. Ruser, U. Briner, H.R. Macke, C. Bruns, Nuclear Medicine and Biology 1998, 25(3), 181-188.

[23] L. Oberer, G. Interlandi, A. Caflisch, G. Bovermann, C. Ehrhardt, I. Lewis, 'Unique Structural Elements Profoundly Influence the Conformation of SOM230', in 'Peptide Revolution: Genomics, Proteomics \& Therapeutics', Eds. M. Chorev, T.K.Sawyer, Proceedings of the 18th American Peptide Symposium, Boston, July 2003.

[24] C. Bruns, I. Lewis, U. Briner, G. MenoTetang, G. Weckbecker, Eur. J. Endocrinol. 2002, 146, 707-716.

[25] G. Weckbecker, U. Briner, I. Lewis, C. Bruns, Endocrinol. 2002, 143(10), 4123-4130.

\section{First Clinical Experiences}

[26] J. van der Hoek, W.W. de Herder, R.A. Feelders, A.-J. van der Lely, P. Uitterlinden, V. Boerlin, C. Bruns, K.W. Poon, I. Lewis, G. Weckbecker, T. Krahnke, L.J. Hofland, S.W. Lamberts, J. Clin. Endocrinol. Metabol. 2004, 89, 638-645.

[27] V. Boerlin, J. van der Hoek, C. Beglinger, K.W. Poon, S. Hartmann, C. Dutreix, J.M. Kovarik, C. Bruns, G. Weckbecker, I. Lewis, P. Schnieper, L. Hofland, S.W.J. Lamberts, J. Endocrinol. Invest., in press.

[28] I. Shimon, X. Yan, J.E. Taylor, M.H. Weiss, M.D. Culler, S. Melmed, J. Clin. Invest. 1997, 100, 2386-2392.

[29] P. Jaquet, A. Saveanu, G. Gunz, F. Fina, A.J. Zamora, M. Grino, M.D. Culler, J.P. Moreau, A. Enjalbert, L.H. Ouafik, J. Clin. Endocrinol. Metab. 2000, 85, 781-92.

[30] R.D. Murray, K. Kim, S.G. Ren, I. Lewis, G. Weckbecker, C. Bruns, S. Melmed, J. Clin. Endocrinol. Metab., in press.

\section{Reviews}

[31] S. Froidevaux, A.N. Eberle, Biopolymers 2002, 66(3), 161-183.

[32] S.W.J. Lamberts, A.J. van der Lely, L.J. Hofland, Eur. J. Endocrinol. 2002, 146(5), 701-705.

[33] W.W. de Herder, L.J. Hofland, A.J. van der Lely, S.W.J. Lamberts, Endocrine-related Cancer, 2003, 10 (4), 451-458.

[34] G. Weckbecker, I. Lewis, R. Albert, H.A. Schmid, D. Hoyer, C. Bruns, Nature Reviews: Drug Discovery 2003, Vol. 2, Nr. 12, 999-1017. 